\title{
Corporate Board Attributes and Dividend Pay-out Policy: Mediating Role of Financial Leverage*
}

\author{
Hussain TAHIR ${ }^{1}$, Ridzuan MASRI ${ }^{2}$, Mahfuzur RAHMAN ${ }^{3}$ \\ Received: October 31, 2019 Revised: November 15, 2019 Accepted: November 20, 2019
}

\begin{abstract}
The relationship between corporate board attributes and dividend payout is already established yet mediating role of leverage in not been examined in Malaysian market. Therefore, this study aims to examine the mediating effect of financial leverage on the relationship between corporate board attributes and the dividend pay-out policy. A sample of 203 non-financial firms listed on the BURSA Malaysia between 2005 and 2018 were analysed using SmartPLS 3.0. The findings show that there is a partial mediating effect of financial leverage on the relationship between board members age, board diversity and dividend pay-out policy. Financial leverage also mediates the relationship between number of women on board, CEO-duality and dividend pay-out policy. However, financial leverage doesn't mediate the relationship between board size and dividend pay-out policy. This study offers insights to policy-makers to develop a better corporate governance as well as a guidance to firms in the construction and implementation of their corporate governance policies in relation to financial leverage. This study also shed light on the influence of efficient corporate board attributes on dividend pay-out policy and financial leverage for firm growth. This study concludes that corporate board attributes impact capital structure and thus, firms may change its payout policy.
\end{abstract}

Keywords : Board Attributes, Financial Leverage, Dividend Pay-out Policy, Malaysia

JEL Classification Code : G32, G34, G35

\section{Introduction}

Firms all over the world want expansion and growth in order to attract investment from investors. Main factor is dividend pay-out policy which can easily attract the investor. Announcement of dividend pay-out policy and the role of

\footnotetext{
* We gratefully acknowledge the funding from the Faculty of Business and Law, International University of Malaya-Wales Malaysia Grant \# IUMW/INT-GRANT/COMMITTEE/2019(1).

1 First Author, PhD Student, IUMW Business School, Faculty of Business and Law, International University of Malaya-Wales, Malaysia. Email: baigtahir3636@yahoo.com

2 Senior Lecturer, IUMW Business School, Faculty of Business and Law, International University of Malaya-Wales, Malaysia. Email: ridzuan@iumw.edu.my

3 Corresponding Author, Senior Lecturer, Faculty of Business and Accountancy, University of Malaya (UM), Malaysia. [Postal Address: 50603 Kuala Lumpur, Malaysia] Email: mahfuzur@um.edu.my

(c) Copyright: Korean Distribution Science Association (KODISA)

This is an Open Access article distributed under the terms of the Creative Commons Attribution Non-Commercial License (http://Creativecommons.org/licenses/by-nc/4.0/) which permits unrestricted noncommercial use, distribution, and reproduction in any medium, provided the original work is properly cited.
}

board attributes and financial leverage in the family-own business is one of the most important research topics in financial management. Corporate board are most influential body of management in corporate firms and authorised for financial decision-making. This is the case because low investment opportunities can distort the efficient allocation of internal funds and destroy firm value. Malaysia ranks top 7 th in family owned business world Credit Suisse Research Institute (CSRI). Most influential body in decision making is corporate board, almost $60 \%$ of Malaysian firms belongs to families and furthermost of the board of directors belong to families they influence in financial decision making. The existing works emphases mostly on examining the aspects of pay-out policy highlighting the reasons why managers pay dividends (Ghasemi \& Keivani, 2013). The effectiveness of corporate board attributes on financial leverage (Jiraporn \& Kim, 2011) and the relationship with dividend pay-out (Abor \& Bokpin, 2010) is very important. Importance of dividend pay-out policy may not ignored in an increase of investment opportunities (Benlemlih, 2019). Additionally, intervening relationship of ownership structure between 
board attribute and dividend pay-out policy is not ignored (Harada \& Nguyen, 2011). Concentrating, whether financial leverage mediates between corporate board attributes on the relationship of company's dividend pay-out policy is vital for the subsequent reason. The impact of corporate board attributes on company's dividend pay-out policy unpleasant. The investigation of the mediating impact of financial leverage and company's dividend pay-out policy could conclude the diverse outcomes regarding the impact of corporate board attributes on company's dividend pay-out policy.

Deprived corporate board attributes management impact the business. For example, when various companies become highly leveraged and or more short-term debt a financial disaster may happen. There are main examples of ASEAN faces Financial Disaster of 1997 and the Global Financial Disaster of 2007. Therefore, literature on the impact of board attributes and company's dividend pay-out policy has been increasing in topical years. Although many studies evolved since the scholarly work board governance and firms performance examined, roughly very few studies literature focuses on board attributes impact on dividend policy (Miller \& Modigliani, 1961). Illustration on the confirmation of the dividend inappropriateness theories in the ideal marketplace affianced with lucid stockholders. Scholars in excess of the world have required to know about corporate board factors affect the dividend pay-out policy (Miller \& Modigliani, 1961). Board attribute comprise with company board size (Fama \& French, 2001), capital structure (Al-Kuwari, 2009). Currently, essential of literature has attentive on the impact of financial leverage on dividend pay-out policy (Harada \& Nguyen, 2011).

It is important to note that the behaviour of the companies depend on the environment of the companies where it operates. For instance, in America, the one-tier board model adopted but the two-tier board model is adopted in Europe like Germany. Factually, same as one-tier board system has been used in Malaysia, but now a day's constant debate of a replacing one-tier board structure to two-tier board structure. The legal structure has a vital influence in reshaping the company's behaviours. Dissimilar the American companies must comply with different sets of laws at the state level and the central levels, companies in Malaysia usually must comply with laws and regulations at a federal level. So, Malaysia companies deal with different laws from America.

This study uses 2,842 firm's observations of Nonfinancial companies in Malaysia. The hypnotically test is conducted to identify the mediating relationship of financial leverage between board attributes and company's dividend pay-out policy. Main and most important conclusions in this paper can be briefly conclude as follows. First, the results display that financial leverage indirectly mediates between board attributes and company's dividend pay-out policy. Secondly, board attributes are related to financial leverage and the company's dividend pay-out, unfortunately, current results opposing the previous finding. Al-Najjar and
Kilincarslan (2016) and Byoun, Chang and Kim (2016) reveal the association between financial leverage and dividend pay-out policy. On the other side, the previous researches (Saeed \& Sameer, 2017; Sawicki, 2009) finds the association between board attributes and company dividend pay-out. Third, for large firms size, CEO duality negatively related to company dividend pay-out ratio. CEO duality is not in the favour of firm financial performance for long run, one reasonable description for the negative association is that the CEO duality performs its responsibilities effectively and hypothetically reduces upward shareholders earnings manipulation.

This study has two main objectives. Primary, study scrutinizes the impact of board attributes on company dividend pay-out policy that may commenced with numerous improvements subsequent to a financial crisis. The additional, study examine whether financial leverage mediates between board attributes and company's dividend pay-out. To discourse the objectives, study scrutinizes a sample of Kuala lumper stock exchange companies in Malaysia for three reasons. Primary, Malaysia has applied several improvements next to the Asian Financial Disaster in 1997-1998. Malaysia began its board attributes reorganizations procedure by necessitating and endorsing a sequence of good corporate governance in 1999s. Second, Malaysia is one of the major emerging markets in ASEAN. Third, the public listed companies in Malaysia function in a one-tier board structure. The progress of board attributes structures in Malaysia shadows that of Hong Kong corporate structure. This study is closely related to the work of Detthamrong and Vithessonthi (2017); Connelly and Nagarajan (2012) and Prommin and Jiraporn (2014). Rendering to the trade-off theory of capital structure, companies pick the ideal arrangement of liability in their capital structure in order to enhance the benefits from the interest tax shield. One of the main reasons for the ASEAN financial Crisis of 1997 affect the firms which was extremely high leveraged.

Firm board size and board member average age and board diversity are positively related to company dividend pay-out. Study measure board diversity by means of a binary variable that receipts a value of one if a firm have one female director on board (Byoun \& Kim, 2016; Saeed \& Sameer, 2017) and zero otherwise. The implementation of corporate laws in the number of multinational companies will assist advance the reliability and accurateness of the company's financial decision-making process. The negative impact of zero diversity seems to suggest that new investment in BURSA Malaysia might be deterred by the zero presence of board diversity in the company. The study is prearranged as follows. Section 2 is comprised of a literature review and hypothesis development. Section 3 hypothesis development. Section 4 comprise with research methodology and descriptive statistics. Section 5 empirical results and model fit. Section 6 is offerings a discussion, conclusion and implication and future research of the study. 


\section{Literature Review}

This section presents the existing literature on corporate board attributes impact on financial decisions of developing countries specifically in Malaysia, after this study focus on mediation role of financial leverage between corporate board attributes and dividend pay-out policy in developing countries perspectives with a focus on Asian Malaysia. At the end of the section, the study derives the hypothesis to be tested. Generally, study add to the literature on boards attributes of companies by investigation circumstances which board attributes impact the company dividend pay-out policy from a big panel data that concealments all publicly listed non-financial companies in Malaysia throughout 2005-2018. This study is closely related to prior studies that examine the effect of corporate board attributes on firm dividend pay-out policy in emerging economies (Chen et al., 2017). Prior to a significant body of literature inspected the dividend pay-out strategies in advanced counties like America (Easterbrook, 1984). The cumulative size of literature (Adaoglu, 2000; Miller \& Shah, 1995) is suggesting substantial variances in dividend pay-out behaviour between developed economies and emerging economies.

\subsection{Relationship between Corporate Board Attributes and Dividend Pay-out}

Firm board attributes framework shapes an atmosphere of accountability, belief and transparency. Firm's board attributes work to decrease the agency problem, because separation of managers and stockholders. Firm's board attributes is a vital instrument to decrease conflicts between administration and owners. Chang et al. (2014) contend that the level of a financial obligation of the company is impacted by both the company's inimitable upcoming conflicts of interest between its administrator and stockholders.

The subsequent subsections deliberate the board attributes and their impact on a financial leverage of the company, and factors that comprise investment opportunities (Abor, \& Bokpin, 2010) and company volume (Fama \& French, 2001; Abor \& Bokpin, 2010) profitability (Abor \& Bokpin, 2010; Amidu, 2006) and financial leverage (AlKuwari, 2009). A currently essential of literature has attentive on the impact of ownership structure on dividend pay-out (Harada \& Nguyen, 2011; Mehrani et al., 2011). For instance, weak governance companies highly leveraged and poor firm performance than strong governed companies (Jiraporn \& Kim, 2011). The good corporate legal system can decrease agency costs. Administrators incline to pursue lower financial leverage when they challenge with the better corporate legal system of the board (Wen, Rwegasira \& Bilderbeek, 2002). Corporate board attributes tools provide a standard to tenacity quarrels between managers to guarantee the stockholders or other attentive investor's that the managers can manage funds in order to maximize the worth of the company. Several other researchers (e.g., Berger, Ofek, \& Yermack, 1997) have found the association between board attributes and firms financial structure.

\subsection{Relationship between Corporate Board Attributes and Financial Leverage}

The impact of board attributes on financial leverage (Marimuthu et al., 2019) is significant. Illustration on the confirmation of the dividend inappropriateness theories in the ideal market affianced with rational investors. Scholars in excess of the world have required knowing the factors of dividend pay-out policy (Miller \& Modigliani, 1961) and factors that comprise investment opportunities (Abor \& Bokpin, 2010), firm's volume (Abor \& Bokpin, 2010; Fama \& French, 2001), abundance (Abor \& Bokpin, 2010; Amidu, 2006) and capital structure (Al-Kuwari, 2009; McGuinness, Lam, \& Vieito, 2015). Additionally, essential of literature has concentrated ownership structure impact on dividend pay-out policy (Harada \& Nguyen, 2011; Mehrani, Moradi, \& Esk, 2011). Another firm endocentric individuality like company size, risk level, investment chance, productivity and financial leverage have also been developed to link with dividend pay-out policy (Abor \& Bokpin, 2010; Al-Kuwari, 2009; Amidu, 2006). This is a worldwide harmony that there is no single ambitious clarification for dividend policy (Abor \& Bokpin, 2010). Since the Miller and Modigliani (1961) study on dividend pay-out policy, the literature of dividend pay-out policy has progressed scholarly.

\subsubsection{Relationship between Corporate Board Attributes and Financial Leverage}

Financial complexity of a company outstanding to its high leverage ratio (Zeng, 2003). There is a relationship between financial leverage, board attributes and dividend pay-out policy (Qureshi et al., 2018). So, discussing the board attributes, innovation investment and dividend payout policy, the role of financial Leverage cannot be ignored (Abor \& Bokpin, 2010; Al-Kuwari, 2009; Amidu, 2006).

\subsubsection{The Mediating Role of Financial Leverage between Corporate Board Attribute and Dividend Pay-out}

The possession arrangement and the firm's financial assets have a significant influence on financial consultancy. Some way to exploit its worth is by increasing the mixture of loan and equity investment to sponsorship its assets making cash flow for the firm. Zeng (2003) supports that if financial leverage is used as a failure to pay timely sign and has a positive association with the cost of finance, consequently paying dividends can boost the financial complexity of a company outstanding to its high leverage ratio. The consequences demonstrate that there is an opposite connection between financial leverage and 
dividend pay-out policy. It was resisted by the same results announced by Fenn and Liang (2001), which identify that there was an inverse course in the association between the two variables. Nash, Netter and Poulsen (2003) also rope the quarrel ascending from the addition of financing contracts to reduce dividend payments by investors. Moreover, Ozdagli (2012) identified the important association between the dividends bid with the firm's linked to financial leverage. The leverage height of the firm will replicate changes in income to its investors. There is a negative connection between financial leverage and dividend pay-out policy. Increase in a financial leverage ratio of the firm, the lower the return to the shareholders as a firm must put up with the outlay to pay back their loans. However, Al-Kuwari (2009) focused that the association among financial leverage and firm dividend payments was encouraging when the most favourable capital structure was capable to announce a high dividend.

Addressing the question of whether financial leverage mediates the impact of board attributes on company dividend pay-out policy is vital for the subsequent reason. First, board attributes may not have a direct impact on company dividend pay-out policy. If the impact of boards attributes on company dividend pay-out policy is indirect, investigative the intervening impact of financial leverage on company dividend pay-out policy could clarify the mixed results concerning the impact of board attributes and dividend pay-out policy. Second, by observing at financial leverage as one of the potential mediators, the study would have a better understanding of how changes in board attributes may impact the company dividend pay-out policy.

\section{Hypotheses Development}

To scrutinize the relationship between corporate board attribute and firm dividend pay-out, study developed thirteen main explanatory hypotheses. The study contends the mediation effect of financial leverage between corporate board attributes and dividend pay-out policy.

\subsection{Board Attributes Relationship with Financial Leverage}

\subsubsection{Board Size and Financial Leverage}

The board's members are one of the most central rudiments of the governance instrument in the supervision of the effective and suitable processes of the firms. Board of directors play a significant role in mitigating the let-down of the firms (Chancharat, Krishnamurti, \& Tian, 2012). Board members of the firms are accountable for monitoring the events and announcing the tactical verdicts.

Study literature review discloses the board of directors' importance in decision making. The board size is not clear in different corporate legal structure. It has been contended that the ideal board size is contingent on the company's physiognomies, managing costs and administrative difficulties (Uchida, 2011). But the BURSA Malaysia has provided the directions that the board should consist of 3 to 15 members, contingent on the scope of the business, and complexity of the firms. Previous researches reveal diverse conclusions concerning the association between board size and financial leverage. On the one hand, Berger et al. (1997) reveal that board size has a negative impact on financial leverage, and another hand, Jensen (1986) disclosed that companies with bigger board size have higher financial leverage than companies with slighter less board size and proposes that companies with the bigger board likely to practice more financial obligation than equity financing. From these views Zahra and Pearce (1989) declared that a bigger board with more members is more appreciated than the ones with fewer members because of their massive information, capitals and outside relations. Corporate board directors comportment can have a huge impact on the firm's market worth (Bhagst \& Black, 2001). The positive association among board volume and financial leverage seems to support the notion that companies with a greater number of board members might have a more external relationship to have healthier access to outside financing. On the basis of above discussion, the study, consequently, proposes the subsequent hypothesis.

H1: The firm's board size is positively related to financial leverage.

\subsubsection{Board Diversity and Financial Leverage}

By definition, the board director's diversity of gender difference in the board members. There is a rising trust that lady board members would be talented to progress the effectiveness of the board of the firm. In this regard, Norway is the leading state that clearly set the number of female members on the board by necessitating that every business essential to have a minimum of $40 \%$ of females on the board. Lady board members are probable to provide the firm's administration by means of their skills and information on lawful, HRM, communication, and public relations more than their male complements (Zelechowski \& Bilimoria, 2004). The largest directors shift directors by their progression to elder manager positions, such a program remains stifled for the woman and opposition directorsusually assigned to being the "glass ceiling effect" (Farrell \& Hersch, 2005; Hillman, Cannella, \& Harris, 2002). Hillman et al. (2002) noted that largest woman and ethnic adolescence directors appear from un-business related professions; all usually extend to a higher echelon of directorship by confirming their outstanding specialist and institutional qualification.

Here means that female and minority directors seem not to participate in the system of associations among different leaders, which are usually developed within their profession ways. The query is then whether feminine members would stab to lessen the company financial leverage so as to decrease financial risk, thus pointing to the negative impact 
of lady managerial position on leverage. Though, given that previous researches (Chang et al., 2014) demonstration that numbers of companies in developed economies have less financial leverage, the existence of lady executives in organizations with low financial leverage may push them to have higher leverage. Some researches that explain sexuality difference has a definite relationship with performance and decision making (Carter, Simkins, \& Simpson, 2003) through further remarkable researches assume that sexuality heterogeneity \& performance are not associated with as whole (Randoy, Thomsen, \& Oxelheim, 2006; Zahra \& Stanton, 1988). So, board diversity is a relationship with financial leverage. Since companies in advance economies are usually more financially constrained than those in emerging economies, study supposes the impact of diverse members in the board of directors on financial leverage to be positive for the former and negative for the latter. In this of discussion the researchers consequently suggest, the following hypothesis:

H2: Board gender diversity is positively associated with financial leverage.

\subsubsection{Board Members Average Age and Financial Leverage}

Board directors with distinct age collection of practical knowledge, trade practices, educated skills, ethnic and sexuality mix force are adequately outfitted to administer broad spectrum of concerns fronting the organization and equip administrators with information and deliberation. Earlier researches have examined how boards' different attributes such as board size (Van Pelt, 2013) and average age and skill (Custódio \& Metzger, 2014) influence the financial leverage and dividend pay-out policy. The impact of board age diversity on company performance is flimsy in the pay-out works (Carter et al., 2010; Urs Waelchlia, 2013). According to Serfling (2014), research on CEO age and hazardousness of corporate strategies, trading strategy that goes long in the portfolio of stock contains companies controlled by younger CEOs and short in the portfolio of stocks including of organization run by aged CEOs would make a constructive risk-adjusted return. Serfling (2014) reveals that on CEO age, underinvestment, and agency cost, argues that age of a CEO can have a significant impact on organization financial policy policies, company performance and the being of agency cost inside an organization. Gilpatrick (2000) investigates that board of director committee is introduced of middle to retirement aged members. It alludes that diversity in age result to contributions due to diverse skills, experience and knowledge from among the older board members which can be learnt by younger members. Therefore, on the above suggestions the study propose the following hypothesis:

H3: Board member average ages are positively associated with financial leverage.

\subsubsection{CEO Duality and Financial Leverage}

CEO duality expresses, the CEO hold the chairmanship of the board of directors (Krenn, 2014). CEO duality is the repetition of combining the $\mathrm{CEO}$ and board of chair hooked on a solitary way (Finkelstein \& D'Aveni, 1994). It affects the board of directors' monitoring capacity (Dalton \& Dalton, 2011) contribute to CEO superior discretion (Dalton \& Kesner, 2017; Hambrick et al., 1987). It can be both good or bad outcomes for firms (Benavides, Berggrun, \& Perafan, 2016; Boyd, 1994; Finkelstein, 1994; Krause, Semadeni, \& Cannella, 2014). A detachment of Board chair, CEO and division of sovereign board organs has achieved distinction in an inquiries concern the raising of corporate governance structure (Perry, 1995). The specific purpose of Board director and CEO are different but cooperative of each other. The board chair is committed by charge for usual administration of board and guaranteeing that all Board organs are equipped to perform a complete part in committee duties. Head coincidentally with Board organs are accountable for controlling, assessing to the representation of the $\mathrm{CEO}$ and his administration unit. CEO and administration unit are sequentially accountable for dayby-day services, to form (with approval of Board) and execute plans for progress and maturity of the firm.

According to Sunday (2008) the firm has accomplished the goals under the way of members of the board who are representatives to the $\mathrm{CEO}$ and other administration. The board members, make available leadership and direct the concerns of the firm with a high intellect of honesty, promise to the firm, its business plans, and long-term shareholder value. When the decision power came in one hand, from different authority seats. The decision power influenced individual interests and decision may affect by individuals. On the basis of above discussion, the study proposes the following hypothesis:

H4: CEO duality is positively associated with financial leverage.

\subsection{The Effects of Corporate Board Attributes on Firm Dividend Pay-out Policy}

Corporate board attributes are the governance of corporate firms and the system of administration and management that impact the purpose and accomplishment of the objectives of the company. It is a means to weigh and control the risk of the company and to guarantee that its application is effective. Good corporate board attributes tools and mechanism encourages companies to make worth through processes, and R\&D. They are liable to offer accountability and passable control mechanism. Asian financial crisis 1997 produced numerous crisis-hit in economies, including Malaysia, to emphasis on making and developing better corporate board attributes mechanisms. It is vital for a business organization to develop cultural awareness, transparency, and accountability, which will help 
in long term value formation and established financial position for the company and its stockholders.

Since the 1997 Asian Financial Crisis, companies in Malaysia as well as in other crisis-hit economies necessity to decrease their weakness/ vulnerability to economic shocks and progress in the firm's board attributes practices. Previous researches (e.g., Al-Shubiri, 2011; Byoun et al., 2016) on the subject of whether a firm's board attributes impact the company dividend pay-out have provided diverse outcomes. In this subdivision, the study progresses the hypotheses concerning the association between a firm's board attributes and firm's dividend pay-out.

\subsubsection{Board Size and Firm Dividend Pay-out Policy}

The size of the board of firm plays a significant character in the executives' aptitude to supervise and control administrators (Anderson, De Dreu, \& Nijstad, 2004). There is a major association established among firm's board size and dividend pay-out (Mansourinia et al., 2013) the research took place on 140 firms of TSE (Tehran stock exchange) for the 5 years' period 2006-10. Investigation identifies the considerably optimistic relationship between board size and dividend pay-out policy. Likewise, a positive association was established among board size and dividend pay-out policy by Uwuigbe (2013) using a regression analysis method.

In addition, Subramaniam et al. (2011) noted major optimistic association between the size of the board and dividend pay-out policy. The consequences show firms with big size of the board and family-owned firms are liable to pay upper dividends. The superior stake of a family forces the managers to allocate profits between the families in the form of a dividend. In learning of Nigerian firms by Uwalomwa, Olamide and Francis (2015) positive association was institute among board size. Towards this end, Afzal and Sehrish (2011) and Mansourinia et al. (2013) pragmatic that board size had a constructive impact on the dividend pay-out. Similarly, Ajanthan (2013) distinguished that board size and dividend pay-out have a relationship but statistically insignificant. Brown (2006) as well as Haniffa and Hudaib (2006) initiate a positive impact of small board size on dividend pay-out. Contrary to above Bolbol (2012) and Conyon and Peck (1998) found a negative and insignificant relationship of a firm's board size with dividend pay-out. Therefore, the study suggests the following hypothesis:

H5: Firm's board size is a positive relationship with firm dividend pay-out policy.

\subsubsection{Board Diversity and Dividend Pay-out Policy}

Board diversity leads to R\&D and imagination. Factually, utmost all boards of members mostly included of male members. In recent years, there is a robust quarrel for taking additional lady member to deliver different opinions that may improve the aptitude of decisions making and firm dividend pay-out. There is an association among gender diversity of the board members and financial performance, finishing that female board sign is positively associated with pay-out (Post \& Byron, 2015). Companies with diverse directors incline to emphasis additional on CSR (Shaukat, Qiu, \& Trojanowski, 2016).

Some researches that explain sexuality difference has a definite relationship with performance and decision making (Carter et al., 2003) through further remarkable researches assume that sexuality heterogeneity \& performance are not associated with as whole (Randoy et al., 2006; Zahra \& Stanton, 1988). So, board diversity is a relationship with financial leverage. Moreover, Hutchinson, Mack and Plastow (2015) introduced that board gender diversity is positively related to company performance. On the other hand, Rose (2007) has found an insignificant connotation among women executives and organization performance of listed companies in Denmark. Therefore, the study suggests the following hypothesis:

H6: Board diversity is positively related to company dividend pay-out policy.

\subsubsection{Board Average Age and Firm Dividend Pay-out} Policy

Generally, researchers focussed on the association among demographic diversity with prominence on gender against company performance. The impact of board age diversity on firm performance is revealing in the literature (Carter et al., 2010; Waelchlia, 2013). Board directors with distinct age collection of practical knowledge, trade practices, educated skills, ethnic and sexuality mix force are adequately outfitted to administer broad spectrum of concerns fronting the organization and equip administrators with information and deliberation. Therefore, Gilpatrick (2000) reveals that boardroom is controlled by mid-aged persons. Conferring to Lick Erath-Rovers, Dutch registered companies signify middle and old board members subsequent to deficiencies in knowledge and advance expertise from younger directors that surely impact financial performance hereafter dividend pay-out policy.

Board directors with distinct age collection of practical knowledge, trade practices, educated skills, ethnic and sexuality mix force are adequately outfitted to administer board spectrum of concerns fronting the organization and equip administrators with information and deliberation. Age diversity affects the firm's performance (Carter et al., 2010). Earlier researches have examined how boards' different attributes such as board size (Van Pelt, 2013) and average age and skill (Custódio \& Metzger, 2014) influence the dividend pay-out policy (Boumosleh, Anwar, 2015), adding to this, by Serfling (2014) chief executive officer age related to innovation investment and agency cast related matters. Chief executive officer age and riskiness of business strategies, investment policies that in a portfolio of stock consists of firms managed by younger chief executive officer (Serfling, 2014). Therefore, there is a relationship between board member agrees with financial decision- 
making. Based on the discussion the following hypothesis is proposed:

H7: Board members average age is positively associated with firm dividend pay-out.

\subsubsection{CEO Duality and Dividend Pay-out Policy}

Normally, CEO duality impacts the company dividend pay-out policy. More specifically, the study expects companies with CEO dual to accomplish poorer than a company with non-CEO duality. Although CEO duality may progress the rapidity of the conclusion that strength is significant throughout the eras of rapidly changing market atmospheres. Proactive decisions could, though, be unsuitable under some conditions. CEOs duality can exercise additional control over their companies incline to a reduction in company worth. Moreover, CEO duality has been visible as one of the main factors for company letdowns like Enron and WorldCom.

CEO duality expresses, the CEO takes the specific office of chair of the board also (Krenn, 2014). CEO duality is the repetition of combining the CEO and board of chair hooked on a solitary way (Finkelstein \& D'Aveni, 1994). CEO duality affects the board of directors' monitoring capacity and contribute to CEO superior discretion (Dalton \& Kesner, 2017) and can be either good or bad outcomes for firms (Benavides et al., 2016; Boyd, 1994; Krause et al., 2014). A detachment of Board chair, CEO and division of sovereign board organs has achieved distinction in an inquiries concern the raising of corporate governance structure (Perry, 1995). The specific purpose of board director and CEO are different but cooperative to each other. The board chair is committed by charge for usual administration of board and guaranteeing that all board organs are equipped to perform a complete part in committee duties. On the basis of above discussion study propose the following hypothesis:

H8: CEO duality is negatively related to dividend pay-out policy.

\subsection{The Impact of Financial Leverage on Firm dividend Pay-out Policy}

Experimental proof on the determinants of dividend policy has mostly paid attention to developed countries with diverse outcomes (Abor \& Bokpin, 2010). The collision of possession structure, in exacting concerted ownership on the company's dividend pay-out in developing markets such as Malaysia relics highly unexplored. More than $60 \%$ of listed companies in emerging market principally in Malaysia is very much penetrating and these companies typically retained by families (Jong, 2018). Prior researches show that intense ownerships are powerfully linked with pyramidal structures that are probable to upsurge the risk of expropriation among minority and controlling shareholders (Claessens et al., 2000).
The possession arrangement and the firm's financial assets have a significant influence on financial constancy. Some way to exploit its value is by increasing the mixture of debt and equity investment to finance its assets generating cash flow for the firm. Javed (2012) recommends that financial leverage is a financial activity concerning increasing funds from outsources and incurring costs to get better. High level of financial leverage of the company may decrease the level dividend pay-out a firm has to put up with the outlay to recompense their debt costs. On the other side, the association among financial leverage and firm dividend payments was encouraging when the most favourable capital structure was capable to pay a high dividend contrast to other companies (Al-Kuwari, 2009). There is another point of view the use of debt financing roots the company financer to check its behaviours more thoroughly and systematically, companies with higher financial leverage would be more probable to invest in safe and good earnings plans and achieve well than companies with lower financial leverage. Consequently, the study proposes the following hypothesis:

H9: Financial leverage is positively associated with firm dividend pay-out policy.

\subsection{The Mediating Role of Financial Leverage on the Relationship between Board Attributes and Firm's Dividend Pay-out Policy}

The study contends that corporate board attributes do not exert its impact on company dividend pay-out policy directly but rather impact company dividend pay-out partially through financial leverage. Dividend pay-out decisions influenced by financial leverage (Al-Shubiri, 2011) support that if financial leverage is used as a failure to pay time sign and has a positive association with the cost of finance, consequently paying dividends can boost the financial complexity of a company outstanding to its high leverage ratio. The consequences demonstrate that there is an inverse association between these two variables. It was resistant by the same results announced by Fenn and Liang (2001) which identify that there was an inverse course in the association between the two variables. Ozdagli (2012) identified that there is a significant association between dividends offer by the firm's and financial leverage, means leverage height of the firm will replicate changes in income to its investors. The weak corporate board attributes may result in high or low financial leverage of the company. Organizations with increased financial leverage are more probable to practice a greater fluctuation in company dividend pay-out, as compare the companies with less financial leverage incline to have fewer fluctuations in dividend pay-out. This substandard level of financial leverage will then impact dividend pay-out policy.

Administrative actions can be simply proscribed by a CEO who is the chairperson of the board of directors as well. So, companies with CEO duality decide to allocate a lower 
dividend as dividends cannot well control agency conflict, though Arshad et al. (2013) check a negative connotation among CEO duality and dividend pay-out in Pakistan. Literature has revealed that financial leverage and dividend pay-out policy play a fundamental position in dropping agency costs, ascending from conflicts between executives and stockholders. Loans are used as a monitoring tool to detect administrators, though dividend pay-out is utilized to avoid self-interest activities by the scheming stockholders (La Porta, 2000). Study propose hypotheses based on the above arguments:

H10: Financial leverage mediate on the relationship between board size and dividend pay- out policy.

H11: Financial leverage mediate on the relationship between board diversity and dividend pay-out policy.

H12: Financial leverage mediate on the relationship between board members average age and dividend pay-out policy.

H13: Financial leverage mediate on the relationship between CEO duality and dividend pay-out policy.

\section{Research Methodology}

In this section, the study discusses nearly key approaches of statistical analysis that can hypothetically applied to addressing the study questions and testing the hypotheses. Reminiscence, research key question is whether financial leverage mediates on the relationship between corporate boards attributes on dividend pay-out. Study unit analysis is company, and study pursues to comprehend the fluctuation of financial leverage impact on board attributes and dividend pay-out policy.

While there are two main research methodologies: (1) the quantitative methodology and (2) the qualitative methodology, in this paper, the quantitative methodology is employed because the quantitative approach is better suited to empirically address the research question than the qualitative approach. More specifically, the qualitative approach, using data collection methods such as interviews and direct observation, is better at addressing the "why" and "how" research questions.

To examine the hypotheses deliberated in Section 2 and the study question that financial leverage mediation role among firm board attributes and company dividend pay-out policy by estimating the path analysis technique using SmartPLS 3.0. To confirm the direction of connection and to addresses the endogeneity concern, the study is utilizing one-legged values for all variables in the right-hand side of all model specifications. It is reasonable to expect that, the other the qualitative method has some limitation on testing these research hypotheses and study questions. To investigate the impact of board attributes on dividend payout, then study estimates the mediating role of financial leverage between board attributes and the firm's dividend pay-out policy.

\subsection{Sample of the Study}

To test the study hypotheses, the research constructs a sample that primarily comprises of all Non-financial firms listed in Malaysia over a 14-year period from 2005 to 2018, with a balanced panel sample of 2,842 firm yearobservations. The study obtained all financial data, firmlevel corporate board attributes from manual from firms' annual reports published by BURSA Malaysia and financial data is collected from Thomson Reuter DataStream.

\subsection{Dependent Variable}

Study measures dividend pay-out policy by (cash dividend/ net income) and study measures a company's financial leverage as the ratio of (total debt / total assets). Numerous researchers (Al-Najjar \& Kilincarslan, 2016; Byoun et al., 2016; McGuinness et al., 2015; PuchetaMartínez \& Bel-Oms, 2016) examined this variables in their study. To test Hypotheses 2-4, the study follows previous researches such as that of (Attig et al., 2016; Bradford, Chen, \& Zhu, 2013; Lam, Sami, \& Zhou, 2012; Saeed \& Sameer, 2017; Sawicki, 2009). Please see a list of variables described in Table 1.

\begin{tabular}{|c|c|c|}
\hline $\begin{array}{l}\text { Variables } \\
\text { code }\end{array}$ & $\begin{array}{l}\text { Variable } \\
\text { name }\end{array}$ & Variables discerption \\
\hline \multicolumn{3}{|c|}{ Independent variables } \\
\hline B_SIZE & Board Size & $\begin{array}{l}\text { Total number of directors } \\
\text { serving on board }\end{array}$ \\
\hline B_AGE & Board Age & $\begin{array}{c}\text { The average age of board } \\
\text { members }\end{array}$ \\
\hline CEO_DUL & CEO Duality & $\begin{array}{c}\text { One, board chairmanship and } \\
\text { CEO are separate, otherwise } \\
\text { zero }\end{array}$ \\
\hline NUM_WOM & $\begin{array}{l}\text { Number of } \\
\text { Women }\end{array}$ & $\begin{array}{c}\text { Number of the woman on } \\
\text { board }\end{array}$ \\
\hline DIV_DUM & $\begin{array}{l}\text { Board } \\
\text { Diversity }\end{array}$ & $\begin{array}{c}\text { One, if women inboard } \\
\text { otherwise zero }\end{array}$ \\
\hline \multicolumn{3}{|c|}{ Mediating variable } \\
\hline FLEV & $\begin{array}{l}\text { Financial } \\
\text { Leverage }\end{array}$ & Total debt / Total assets \\
\hline \multicolumn{3}{|c|}{ Dependent variable } \\
\hline DPR_NI & $\begin{array}{l}\text { Dividend Pay- } \\
\text { out }\end{array}$ & Dividend dividend/ Net Income \\
\hline
\end{tabular}

\subsection{Independent Variables}

To test the impact of board attributes, and financial leverage on firm dividend pay-out policy, the study uses four measures of board attributes, which are in line with previous researches (Byoun et al., 2016; McGuinness et al., 2015). Consistent with (Byoun et al., 2016; Byoun, Chang, Kim, \& Heights, 2011; Pahi \& Yadav, 2018) board size is measured as the number of all board directors Female directorship is measured by the number of female directors from the 
number of all directors, board diversity dichotomies variable one is only for presence of one female director is one otherwise zero (Pucheta-Martínez \& Bel-Oms, 2016; Saeed, Belghitar, \& Yousaf, 2016; Sila, Gonzalez, \& Hagendorff, 2016). Board age average age of board member, present in the board, (Byoun, Chang, \& Kim 2016). ; CEO duality is a dummy variable, which takes a value of one if the CEO is also the chairperson of the board, and zero otherwise (Ntim, et al., 2016).

\subsection{Descriptive Statistics}

Table 2 displays the descriptive statistics of the variables used in this study for the final sample of 2,842 firms-year observations over the period of 2005-2018. The mean and S.D value of B_SIZE is 7.42 (1.851), whereas the mean (S.D) value of B_DUL is 0.709 (0.454). The mean (S.D) value of DPR_NI is $0.0228(0.433)$, whereas the mean (S.D) value of FLEV is $0.183(0.179)$. The mean (S.D) value of B_AGE is 56.27 (5.467), propose that the average companies in Malaysia are not over-leveraged. Board diversity is comprised of a diverse dummy and the number of women in a board.

Table 2: Descriptive Statistics

\begin{tabular}{|c|c|c|c|c|c|}
\hline Variable & Obs & Mean & $\begin{array}{c}\text { Std. } \\
\text { Dev }\end{array}$ & Min & Max \\
\hline DPR_NI & 2,842 & 0.228 & 0.433 & -3.644 & 3.084 \\
\hline FLEV & 2,842 & 0.183 & 0.179 & 0 & 2.916 \\
\hline B_SIZE & 2,842 & 7.423 & 1.851 & 3 & 5 \\
\hline B_AGE & 2,842 & 56.270 & 5.467 & 39.75 & 76.83 \\
\hline DIV_DUM & 2,842 & 0.503 & 0.500 & 0 & 1 \\
\hline NUM_WOM & 2,842 & 0.718 & 0.837 & 0 & 5 \\
\hline CEO_DUL & 2,842 & 0.709 & 0.454 & 0 & 1 \\
\hline
\end{tabular}

\section{Empirical Results}

\subsection{Model Fit}

This method represents a valuable and easy to understand results. Table 3 assessed the level of goodness of fit index. Study using variables without items so that is way NFI is 1 and the colour is green means that the collinearity statistics is 1 for all variables. The first set of analysis examined the effect of board attributes on financial leverage and financial leverage impact on dividend pay-out policy. Investigations took pleased to identify the mediation impact of financial leverage on the relationship between board attribute and dividend pay-out policy. Adj R2 is 0.049 for the dependent variable and Adjusted R2 is 0.012 for FLEV.

Model fitness identify by SRMR Table 3, is significant at $* * *$ means that the model is fit to observe the exogenous to endogenous variables. SRMR stand for Standardized Root Mean Square Residual. Model fit testing using metrics such as SRMR or exact fit tests (Henseler, 2017; Lohmoller, 1989) should be considered with extreme caution due to their conceptual shortcomings in the context of PLS-SEM (Shmueli, Hair, Ting, \& Ringle, 2019).The SRMR is an absolute measure of fit and is distinct as the standardized difference between the observed correlation and the predicted correlation.

Table 3: Model Fit

\begin{tabular}{|c|c|c|}
\hline & Saturated Model & Estimated Model \\
\hline SRMR & 0.000 & 0.000 \\
\hline d_ULS & 0.000 & 0.000 \\
\hline d_G & 0.000 & 0.000 \\
\hline Chi-Square & & 0.000 \\
\hline NFI & 1.000 & 1.000 \\
\hline
\end{tabular}

Table 4 shows that board size is negatively linked with CEO duality, audit committee and dividend and positively linked with board members age. Moreover, board size is significantly related to $\mathrm{CEO}$ duality. CEO duality is positively associated with the board size and positively correlated with board members average age and negatively correlated with board diversity. However, CEO duality has a significant association with the board size but its relationship with board of directors' average age and board diversity is insignificant. The board member average age has a positive relationship with the board size and board members average age.

Table 4: Correlation Matrix

\begin{tabular}{|l|c|c|c|c|c|c|c|c|}
\hline & & $\mathbf{1}$ & $\mathbf{2}$ & $\mathbf{3}$ & $\mathbf{4}$ & $\mathbf{5}$ & $\mathbf{6}$ & $\mathbf{7}$ \\
\hline $\mathbf{1}$ & DPR_NI & 1.0000 & & & & & \\
\hline $\mathbf{2}$ & FLEV & -0.1126 & 1.0000 & & & & \\
\hline $\mathbf{3}$ & B_SIZE & 0.1199 & -0.0074 & 1.0000 & & & \\
\hline $\mathbf{4}$ & B_AGE & 0.1539 & -0.0694 & 0.0129 & 1.0000 & & \\
\hline $\mathbf{5}$ & CED_DUL & 0.0092 & -0.0558 & -0.0984 & 0.0673 & 1.0000 & & \\
\hline $\mathbf{6}$ & DIV_DUM & 0.0593 & -0.0297 & 0.1331 & -0.0760 & 0.1094 & 1.0000 & \\
\hline $\mathbf{7}$ & NUM_W & 0.0376 & 0.0134 & 0.1510 & -0.0982 & 0.0982 & 0.8519 & 1.0000 \\
\hline
\end{tabular}

\subsection{Path Analysis}

In this study, the firm's board size, board average age, board diversity and CEO duality are proxies of board attributes. In the model CEO duality, the number of women, board diversity, board average age and board size, are observed in individually as independent variables. Financial Leverage is the mediator between board attributes and dividend pay-out policy. According to Hayes (2009), if variable $\mathrm{X}$ exerts an effect on the outcome $\mathrm{Y}$ through one or 
more intervening variable it is called meditation.

As initial sample of 2,842 firm year-observation from 2005 to 2018 completed and returned to the conclusion of the study, board attributes relationship is identified with financial leverage. The board diversity, board age and CEO Duality have a significant relationship with financial leverage, and financial leverage has a significant relation with dividend pay-out policy in the appearance of board attributes. No significant relationship was identified between board sizes and financial leverage, insignificant relationship was observed between the number of women and dividend pay-out policy. Same like CEO duality and dividend pay-out have an insignificant relationship (Table 5).
The relationship between boards attributes and financial leverage is interesting because financial leverage was functioning as a mediator between board attribute and dividend pay-out policy. In path coefficient five out of four board attributes effects significantly with financial leverage. Therefore, mediation of financial leverage between board attribute and dividend pay-out policy is identified. The relationship between financial leverage and dividend payout worth mentioning because cutting-edge correlation matrix the financial leverage has negatively relationship with dividend pay-out. If the financial leverage goes high dividend pay-out will go down (Figure 1).

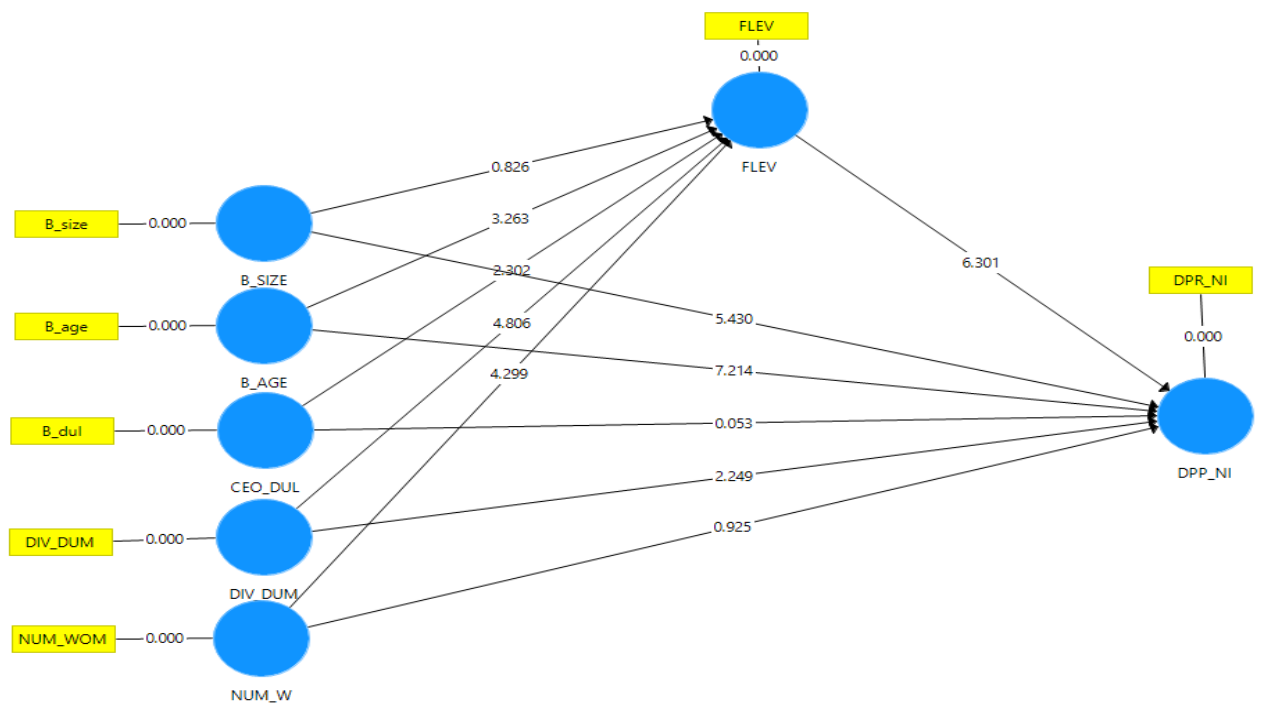

Figure 1: Path Coefficients

Table 5: Path Coefficients

\begin{tabular}{|c|c|c|c|c|c|}
\hline 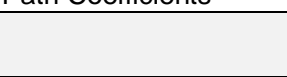 & $\begin{array}{c}\text { Original } \\
\text { Sample (0) }\end{array}$ & $\begin{array}{c}\text { Sample Mean } \\
\text { (M) }\end{array}$ & $\begin{array}{c}\text { Standard } \\
\text { Deviation (STDEV) }\end{array}$ & $\begin{array}{l}\text { T Statistics } \\
\text { (|O/STDEV|) }\end{array}$ & P Values \\
\hline B_AGE -> DPP_NI & 0.149 & 0.149 & 0.021 & 7.214 & $0.000^{\star \star *}$ \\
\hline B_AGE -> FLEV & -0.064 & -0.064 & 0.020 & 3.263 & $0.001^{* * *}$ \\
\hline B_SIZE -> DPP_NI & 0.111 & 0.111 & 0.021 & 5.430 & $0.000^{\star \star *}$ \\
\hline B_SIZE -> FLEV & -0.013 & -0.013 & 0.016 & 0.826 & 0.409 \\
\hline CEO_DUL -> DPP_NI & -0.001 & -0.001 & 0.019 & 0.053 & 0.958 \\
\hline CEO_DUL -> FLEV & -0.050 & -0.051 & 0.022 & 2.302 & $0.022^{* *}$ \\
\hline DIV_DUM -> DPP_NI & 0.083 & 0.082 & 0.037 & 2.249 & $0.025^{\star \star}$ \\
\hline DIV_DUM -> FLEV & -0.145 & -0.143 & 0.030 & 4.806 & $0.000^{\star \star \star}$ \\
\hline FLEV $->$ DPP_NI & -0.099 & -0.099 & 0.016 & 6.301 & $0.000^{\star \star *}$ \\
\hline NUM_W -> DPP_NI & -0.035 & -0.034 & 0.038 & 0.925 & 0.356 \\
\hline NUM_W_W -> FLEV & 0.138 & 0.137 & 0.032 & 4.299 & $0.000^{* * *}$ \\
\hline
\end{tabular}

The single most striking observation to emerge from the data comparison was the identification of financial leverage mediate between board attributes (board size, board member age, board diversity and CEO duality) and dividend pay-out policy. Specific indirect effects are utilized to identify the mediation of financial leverage and identifies a partially mediation between board members average age, board diversity dummy variable between dividend pay-out policy. Moreover, financial leverage has directly mediated between the number of women and CEO duality and dividend payout policy. There is no mediation identifies between board size and dividend pay-out policy. But interestingly there is reverse mediation identify between board size, financial leverage and dividend pay-out policy means dividend pay- 
out mediates between financial leverage and board attributes

(Table 6).

Table 6: Specific Indirect Effects

\begin{tabular}{|c|c|c|c|c|c|c|}
\hline & $\begin{array}{c}\text { Original } \\
\text { Sample }\end{array}$ & $\begin{array}{c}\text { Sample } \\
\text { Mean }\end{array}$ & $\begin{array}{c}\text { Standard } \\
\text { Deviation }\end{array}$ & T Statistics & P Values & Decision \\
\hline B_AGE -> FLEV -> DPP_NI & 0.006 & 0.006 & 0.002 & 2.793 & $0.005^{\star *}$ & Partial mediation \\
\hline B_SIZE -> FLEV -> DPP_NI & 0.001 & 0.001 & 0.002 & 0.811 & 0.418 & No Mediation \\
\hline CEO_DUL -> FLEV -> DPP_NI & 0.005 & 0.005 & 0.002 & 2.153 & $0.032^{\star *}$ & Full Mediation \\
\hline DIV_DUM -> FLEV -> DPP_NI & 0.014 & 0.014 & 0.004 & 3.749 & $0.000^{\star \star *}$ & Partial Mediation \\
\hline NUM_W -> FLEV -> DPP_NI & -0.014 & -0.014 & 0.004 & 3.427 & $0.001^{* * *}$ & Full Mediation \\
\hline
\end{tabular}

\section{Discussion and Conclusion}

\subsection{Discussion}

Main results can be encapsulated as follows. First, board attributes are related to financial leverage which endorse by previous studies (Berger et al., 1997; Wen et al., 2002) reveal the existence of the association among board attributes and financial leverage. Board size relationship between financial leverage is negative, that support by (Berger et al., 1997) reveal negative association among board size and financial leverage. Second, the positive association between board diversity and financial leverage means boardroom might be able to discourse the firm's having an unreasonably low ratio of debt capital to equity capital issue that may happen when the administrator is too risk-averse, that contradict with prior researches by (Chang et al., 2014; McGuinness et al., 2015) reveal that number of companies in developed economies have under-leverage the existence of lady board members in companies with underleverage may push them to have higher financial leverage.

The board diversity in boardroom provides valuable suggestions may help the company knock into better financial decision making. This line of cognitive is in line with previous works such as that of lady board members are probable to sustenance the firm's administration by utilizing their skills, knowledge on legal issues, and also using their skills in HRM, communication, and public relations more than their male counterparts (Zelechowski \& Bilimoria, 2004). Third, for companies, board size is negatively related to financial leverage that in contradict contrary to previous researches (Berger et al., 1997) which negative impact seems to propose that companies with the big board in size are more probable to be comparatively more traditional with admiration to a financial choice, thereby leading to lower financial leverage. Fourth, companies with CEO duality have inferior financial leverage than companies without CEO duality. These detections look to sustain the companies that the members of the board are influenced by CEO duality. Under such circumstances, the CEO and chairman who is more risk-averse could pursue a low leverage policy that may decrease both the risk and the firm's pay-out. This detection is alike to previous researches (Benavides et al., 2016; Boyd, 1994).

Fifth, board attributes are related to the company's dividend pay-out, which looks same to prior studies ( Boumosleh \& Cline, 2015); Custódio \& Metzger, 2014; Sawicki, 2009; Van Pelt, 2013) introduced the existence of the association among board attributes and firm dividend pay-out policy. Sixth, financial leverage is negatively correlated to company dividend pay-out policy, measured as dividend pay-out ratio, for the full sample and all firms size. This detection is in line with previous researches. One reasonable cause for the negative association is that when the financial leverage is less the firms announce better dividend otherwise the restriction of financers may affect the dividend pay-out policy. Same as, it is important to note that some studies (Al-Najjar \& Kilincarslan, 2016; Byoun et al., 2016; McGuinness et al., 2015; Pucheta-Martínez \& BelOms, 2016) reveal that the impact of financial leverage on company dividend pay-out is negative. Lastly, the conclusive findings that the financial leverage partially mediates the association among board attributes and company's dividend pay-out. However, in the mediation path analysis, the study observes that among five indicators of board attributes, board average age and board diversity and the number of women on board CEO duality is significantly related to financial leverage. This finding is novel because previous researches have not scrutinized the mediating role of financial leverage between firm's board attributes and a firm's dividend pay-out policy.

\subsection{Conclusion}

Corporate board attributes are one of the most recent interesting subjects to examine in East Asia, particularly in the outcome of companies' let-downs after ASEAN financial crisis 1997, and other reason may be the most two main questions have often been enquired: First, can strong board attributes reduce the company's risk? Second, do companies with strong board attributes achieve better, those with weak board attributes? Although empirical conclusions seem to be diverse, number lawmakers' body around the world has company beliefs that strong board attributes mechanism would decrease the likelihood of the company taking on excessive risk on over-leveraged and improve company dividend pay-out. In the current study, the paper uses a large sample that covers Non-financial companies listed in Kuala lumper stock exchange (BURSA Malaysia) throughout the period of 2005-2018 to lean-to bright on of the associations 
between board attributes, financial leverage, and firm dividend pay-out policy. The study find for an average firm, corporate board attributes (i.e., the board size, board members average age, female board members, CEO duality) has less effect on financial leverage and dividend pay-out policy. However, study find that financial leverage partially mediates the effect of board member average age, board diversity and the number of women on firm dividend payout policy for firms. To the best of our knowledge, the study is one of the first to show that corporate board attributes exert the indirect effect on firm dividend pay-out policy through financial leverage for companies in an emerging market.

\section{References}

Abbas, M., Qureshi, S. U., Ahmed, M. M., \& Rizwan, M. (2018). Corporate Governance and dividend payout policy: Mediating role of leverage. Pakistan Journal of Social Sciences, 38(1), 62-86.

Abor, J., \& Bokpin, G. A. (2010). Investment opportunities, corporate finance, and dividend payout policy. Studies in Economics and Finance, 27(3), 180-194. https://doi.org/10.1108/10867371011060018

Adaoglu, C. (2000). Instability in the dividend policy of the Istanbul Stock Exchange (ISE) corporations: Evidence from an emerging market. Emerging Markets Review, 1(3), 252-270.

Afzal, M., \& Sehrish, S. A. B. A. (2011). Ownership structure, board composition and dividend policy in Pakistan. African Journal of Business Management, 7(1), 811-817.

Ajanthan, A. (2013). The relationship between dividend payout and firm profitability: A study of listed hotels and restaurant companies in Sri Lanka. International Journal of Scientific and Research Publications, 3(5), 1-6.

Al-Kuwari, D. (2009). Determinants of the dividend policy in emerging stock exchanges: The case of GCC countries. Global Economy \& Finance Journal, 2(2), 38-63.

Al-Najjar, B., \& Kilincarslan, E. (2016). The effect of ownership structure on dividend policy: Evidence from Turkey. Corporate Governance: The International Journal of Business in Society, 16(1), 135-161.

Al-Shubiri, F. N. (2011). Determinants of changes dividend behavior policy: Evidence from the Amman stock exchange. Far East Journal of Psychology and Business, 4(2), 1-15.

Amidu, A. (2006). Determinants of dividend payout ratios in Ghana. Journal of Risk Finance, 7(2), 136-145.

Anderson, N., De Dreu, C. K. W., \& Nijstad, B. A. (2004). The routinization of innovation research: A constructively critical review of the state-of-the-science. Journal of Organizational Behavior, 25(2), 147-173.

Arshad, Z., Akram, Y., Amjad, M., \& Usman, M. (2013). Ownership structure and dividend policy. Interdisciplinary Journal of Contemporary Research in
Business, 5(3), 378-401.

Attig, N., Boubakri, N., El Ghoul, S., \& Guedhami, O. (2016). The global financial crisis, family control, and dividend policy. Financial Management, 45(2), 291-313.

Benavides, J., Berggrun, L., \& Perafan, H. (2016). Dividend payout policies: Evidence from Latin America. Finance Research Letters, 17, 197-210.

Benlemlih, M. (2019). Corporate social responsibility and dividend policy. Research in International Business and Finance, 47, 114-138.

Berger, P. G., Ofek, E., \& Yermack, D. L. (1997). Managerial entrenchment and capital structure decisions. Journal of Finance, 52(4), 1411-1438.

Bhagst, S., \& Black, B. S. (2001). The Non-correlation between board independence and long-term firm performance. Journal of Corporation Law, 27, 231-273.

Boumosleh, A., \& Cline, B. N. (2015). Outside director stock options and dividend policy. Journal of Financial Services Research, 47(3), 381-410.

Boyd, B. K. (1994). Board control and CEO compensation. Strategic Management Journal, 15(5), 335-344.

Bradford, W., Chen, C., \& Zhu, S. (2013). Cash dividend policy, corporate pyramids, and ownership structure: Evidence from China. International Review of Economics and Finance, 27, 445-464.

Byoun, S., Chang, K., \& Kim, Y. S. (2016). Does corporate board diversity affect corporate payout policy? AsiaPacific Journal of Financial Studies, 45(1), 48-101.

Carter, D. A., D’Souza, F., Simkins, B. J., \& Simpson, W. G. (2010). The gender and ethnic diversity of US boards and board committees and firm financial performance. Corporate Governance: An International Review, 18(5), 396-414.

Carter, D. A., Simkins, B. J., \& Simpson, W. G. (2003). Corporate governance, board diversity, and firm value. Financial Review, 38(1), 33-53.

Chancharat, N., Krishnamurti, C., \& Tian, G. (2012). Board structure and survival of new economy IPO firms. Corporate Governance: An International Review, 20(2), 144-163.

Chang, Y.-K., Chou, R. K., \& Huang, T.-H. (2014). Corporate governance and the dynamics of capital structure: New evidence. Journal of Banking \& Finance, 48, 374-385.

Chen, J., Leung, W. S., \& Goergen, M. (2017). The impact of board gender composition on dividend payouts. Journal of Corporate Finance, 43, 86-105.

Claessens, S., Djankov, S., \& Lang, L. H. (2000). The separation of ownership and control in East Asian corporations. Journal of Financial Economics, 58(1-2), 81-112.

Connelly, J. T., Limpaphayom, P., \& Nagarajan, N. J. (2012). The effect of ownership structure and corporate governance on firm value in Thailand. Journal of Banking \& Finance, 36(6), 1722-1743.

Conyon, M. J., \& Peck, S. I. (1998). Board control, remuneration committees, and top management 
compensation. Academy of Management Journal, 41(2), $146-157$.

Custódio, C., \& Metzger, D. (2014). Financial expert CEOs: $\mathrm{CEO}^{\prime} \mathrm{s}$ work experience and firm' s financial policies. Journal of Financial Economics, 114(1), 125-154.

Dalton, D. R., \& Dalton, C. M. (2011). Integration of micro and macro studies in governance research: CEO duality, board composition, and financial performance. Journal of Management, 37(2), 404-411.

Dalton, D. R., \& Kesner, I. F. (1987). Composition and CEO duality in boards of directors: An international perspective. Journal of International Business Studies, 18(3), 33-42.

Detthamrong, U., Chancharat, N., \& Vithessonthi, C. (2017). Corporate governance, capital structure and firm performance: Evidence from Thailand. Research in International Business and Finance, 42, 689-709.

Easterbrook, F. H. (1984). Two agency-cost explanations of dividends. The American Economic Review, 74(4), 650659.

Elmagrhi, M. H., Ntim, C. G., \& Wang, Y. (2016). Antecedents of voluntary corporate governance disclosure: A post-2007/08 financial crisis evidence from the influential UK Combined Code. Corporate Governance, 16(3), 507-538.

Fama, E. F., \& French, K. (2001). Disappearing dividends: Changing firm characteristics or lower propensity to pay? Journal of Financial Economics, 60(1), 3-43.

Farrell, K. A., \& Hersch, P. L. (2005). Additions to corporate boards: The effect of gender. Journal of Corporate Finance, 11(2), 85-106.

Fenn, G. W., \& Liang, N. (2001). Corporate payout policy and managerial. Journal of Financial Economics, 60, $45-72$.

Finkelstein, S., Cannella, S. F. B., Hambrick, D. C., \& Cannella, A. A. (2009). Strategic leadership: Theory and research on executives, top management teams, and boards. New York: Oxford University Press.

Finkelstein, S., \& D'Aveni, R. (1994). CEO duality as a double-edged sword: How boards of directors balance entrenchment avoidance and unity of command author. The Academy of Management Journal, 37(5), 1079-1108.

Ghasemi, R. S., Madrakian, H., \& Keivani, F. S. (2013). (2013). The relationship between the corporate governance and the stock institutional ownership with the dividend: A case study of Tehran. Journal of Business and Management, 15(2), 65-69.

Gilpatrick, K. (2000). Invite youthful insight. Credit Union Management, 23(9), 28-28.

Glen, J. D., Karmokolias, Y., Miller, R. R., \& Shah, S. (1995). Dividend policy and behavior in emerging markets: To pay or not to pay (No. 26), The World Bank.

Hambrick, D. C., \& Finkelstein, S. (1987). Managerial discretion: A bridge between polar views of organizational outcomes. Research in Organizational Behavior, 9, 369-406.

Haniffa, R., \& Hudaib, M. (2006). Corporate governance structure and performance of Malaysian listed companies. Journal of Business Finance and Accounting, 33(7-8), 1034-1062.

Harada, K., \& Nguyen, P. (2011). Ownership concentration and dividend policy in Japan. Managerial Finance, 37(4), 362-379.

Hayes, A. F. (2009). Beyond Baron and Kenny: Statistical mediation analysis in the new millennium. Communication Monographs, 76(4), 408-420.

Henseler, J. (2017). Partial least squares path modeling. In P. Leeflang, J. Wieringa, T. Bijmolt, \& K. Pauwels (Eds.), Advanced methods for modeling markets. International Series in Quantitative Marketing. Cham, CH: Springer.

Hillman, A. J., Cannella Jr., A. A., \& Harris, I. C. (2002). Women and racial monorities in the boardroom: How do they differ? Journal of Management, 28(6), 747-763.

Hutchinson, M., Mack, J., \& Plastow, K. (2015). Who selects the 'right'directors? An examination of the association between board selection, gender diversity and outcomes. Accounting \& Finance, 55(4), 1071-1103.

Jong, L. (2018). Executive remuneration of listed family companies in Malaysia. Western Australia: Doctorial dissertation, Curtin University in Bentley and Perth.

Javed, M. U. (2012). Impact of financial leverage on dividend policy: Case of Karachi Stock Exchange 30 Index. Journal of Contemporary Issues in Business Research, 1(1), 28-32.

Jensen, M. C. (1986). Agency costs of free cash flow, corporate finance, and takeovers. The American Economic Review, 76(2), 323-329.

Jiraporn, P., \& Kim, J. (2011). Dividend payouts and corporate governance quality: An empirical. Review Literature and Arts of the Americas, 46, 251-279.

Krause, R., Semadeni, M., \& Cannella Jr., A. A. (2014). CEO duality: A review and research agenda. Journal of Management, 40(1), 256-286.

Krenn, M. (2014). CEO duality: Economic and sociopsychological determinants. Journal of Leadership, Accountability and Ethics, 11(3), 141-154.

La Porta, R. (2000). Investor protection and corporate governance. Journal of Financial Economics, 58(1-2), 3-27.

Lam, K. C. K., Sami, H., \& Zhou, H. (2012). The role of cross-listing, foreign ownership and state ownership in dividend policy in an emerging market. China Journal of Accounting Research, 5(3), 199-216.

Lohmöller, J. B. (1989). Predictive vs. Structural Modeling: PLS vs. ML. In Latent Variable Path Modeling with Partial Least Squares. Heidelberg, Germany: Springer.

Mansourinia, E., Emamgholipour, M., Rekabdarkolaei, E. A., \& Hozoori, M. (2013). The effect of board size, board independence and CEO duality on dividend policy of companies. International Journal of Economy, Management and Social Sciences, 2(6), 237-241.

Marimuthu, M., Arokiasamy, L., Kaliyamoorthy, M., \& Ranganathan, U. (2019). Board characteristics and dividend pay-out practice among the financially 
distressed firms in Malaysia. Global Business \& Management Research, 11(1), 472-477.

McGuinness, P. B., Lam, K. C., \& Vieito, J. P. (2015). Gender and other major board characteristics in China: Explaining corporate dividend policy and governance. Asia Pacific Journal of Management, 32(4), 989-1038.

Mehrani, S., Moradi, M., \& Esk, H. (2011). Ownership structure and dividend policy: Evidence from Iran. African Journal of Business Management, 5(17), 75167525.

Miller, M., \& Modigliani, F. (1961). Dividend policy, growth, and the valuation of shares. Chicago, IL: University of Chicago Press.

Nash, R. C., Netter, J. M., \& Poulsen, A. B. (2003). Determinants of contractual relations between shareholders and bondholders: Investment opportunities and restrictive covenants. Journal of Corporate Finance, 9(2), 201-232.

Randoy, T., Thomsen, S., \& Oxelheim, L. (2006). A Nordic perspective on corporate board diversity. Age, 390(0.5428), 1-26.

Ozdagli, A. K. (2012). Financial leverage, corporate investment, and stock returns. The Review of Financial Studies, 25(4), 1033-1069.

Pahi, D., \& Yadav, I. S. (2018). Role of corporate governance in determining dividend policy: Panel evidence from India. International Journal of Trade, Economics and Finance, 9(3), 111-115.

Perry, J. P. (1995). The Cadbury Committee and corporate governance in UK. CPA Journal, 65(5), 24-28.

Post, C., \& Byron, K. (2015). Women on boards and firm financial performance: A meta-analysis. Academy of Management Journal, 58(5), 1546-1571.

Prommin, P., Jumreornvong, S., \& Jiraporn, P. (2014). The effect of corporate governance on stock liquidity: The case of Thailand. International Review of Economics \& Finance, 32, 132-142.

Pucheta-Martínez, M. C., \& Bel-Oms, I. (2016). The board of directors and dividend policy: The effect of gender diversity. Industrial and Corporate Change, 25(3), 523547.

Rose, C. (2007). Does female board representation influence firm performance? The Danish evidence. Corporate Governance: An International Review, 15(2), 404-413.

Saeed, A., Belghitar, Y., \& Yousaf, A. (2016). Firm-level determinants of gender diversity in the boardrooms: Evidence from some emerging markets. International Business Review, 25(5), 1076-1088.

Saeed, A., \& Sameer, M. (2017). Impact of board gender diversity on dividend payments: Evidence from some emerging economies. International Business Review, 26(6), 1100-1113.

Sawicki, J. (2009). Corporate governance and dividend policy in Southeast Asia pre- and post-crisis. The European Journal of Finance, 15(2), 211-230.

Serfling, M. A. (2014). CEO age and the riskiness of corporate policies. Journal of Corporate Finance, 25,
251-273.

Shaukat, A., Qiu, Y., \& Trojanowski, G. (2016). Board attributes, corporate social responsibility strategy, and corporate environmental and social performance. Journal of Business Ethics, 135(3), 569-585.

Shmueli, G., Sarstedt, M., Hair, J., Cheah, J., Ting, H., Vaithilingam, S. \& Ringle, C. (2019). Predictive model assessment in PLS-SEM: Guidelines for using PLS predict. European Journal of Marketing, 53(11), 23222347.

Sila, V., Gonzalez, A., \& Hagendorff, J. (2016). Women on board: Does boardroom gender diversity affect firm risk? Journal of Corporate Finance, 36, 26-53.

Subramaniam, R., Devi, S. S., \& Marimuthu, M. (2011). Investment opportunity set and dividend policy in Malaysia. African Journal of Business Management, 5(24), 10128-10143.

Kajola, S. O. (2008). Corporate governance and firm performance: The case of Nigerian listed firms. European Journal of Economics, Finance and Administrative Sciences, 14(14), 16-28.

Uchida, K. (2011). Does corporate board downsizing increase shareholder value? Evidence from Japan. International Review of Economics \& Finance, 20(4), 562-573.

Vintila, G., \& Gherghina, S. C. (2012). An empirical investigation of the relationship between corporate governance mechanisms, CEO characteristics and listed companies' performance. International Business Research, 5(10), 175-191.

Waelchli, U., \& Zeller, J. (2013). Old captains at the helm: Chairman age and firm performance. Journal of Banking \& Finance, 37(5), 1612-1628.

Uwalomwa, U., Olamide, O., \& Francis, I. (2015). The effects of corporate governance mechanisms on firms dividend payout policy in Nigeria. Journal of Accounting and Auditing: Research \& Practice, 2015(2015), 1-11. DOI: $10.5171 / 2015.313679$

Uwuigbe, O. R. (2013). Corporate governance and share price: Evidence from listed firms in Nigeria. African Research Review, 7(2), 129-143.

Van Pelt, T. (2013). The effect of board characteristics on dividend policy. Unpublished Working Paper, Tilburg School of Economics and Management, Department of Finance. Tilburg University: The Netherlands, 1-62.

Wen, Y., Rwegasira, K., \& Bilderbeek, J. (2002). Corporate governance and capital structure decisions of the Chinese listed firms. Corporate Governance: An International Review, 10(2), 75-83.

Zahra, S. A., \& Pearce, J. A. (1989). Boards of directors and corporate financial performance: A review and integrative model. Journal of Management, 15(2), 291334.

Zahra, S. A., \& Stanton, W. W. (1988). The implications of board of directors composition for corporate strategy and performance. International Journal of Management, 5(2), 229-236. 
Hussain TAHIR, Ridzuan MASRI, Mahfuzur RAHMAN / Journal of Asian Finance, Economics and Business Vol 7 No 1 (2020) 167-181

Zelechowski, D. D., \& Bilimoria, D. (2004). Characteristics of women and men corporate inside directors in the US. Corporate Governance: An International Review, 12(3), $337-342$.
Zeng, T. (2003). What determines dividend policy: A comprehensive test? Journal of American Academy of Business, 2(2), 304-304. 